\title{
Studies of the Plymouth Brachyura. I. The Rearing of Crabs in Captivity; with a Description of the Larval Stages of Inachus Dorsettensis, Macropodia longirostris and Maia squinado.
}

\author{
By \\ Marie V. Lebour, D.Sc. \\ Naturalist at the Plymouth Laboratory. \\ With 4 Plates.
}

IT is difficult to rear crabs from the egg, and few experiments of the kind have been successful. It is intended in these studies of the Plymouth Brachyura to rear as many species as possible from the berried crab, and thus to ascertain without doubt the larvæ of each species in all stages, so that they may be recognisable in the plankton.

The members of the Oxyrhyncha so far observed in the Plymouth district are the following :-

Inachus Dorsettensis (Pennant), Inachus Dorynchus Leach, Macropodia longirostris (Fabricius), Macropodia Egyptia A. Milne-Edwards, Macropodia rostratus (L.), Achcus Cranchii Leach, Maia squinado (Herbst), Pisa biaculeata (Montagu), Hyas araneus (L.), Hyas coarcticus Leach, Eurynome aspera (Pennant).

Unfortunately, Williamson (1915) calls all these Inachus, except Maia and Eurynome, which causes much confusion. Three sub-families of the Maiidæ are usually recognised (Borradaile, 1907; Rathbun, 1925); the Inachinæ, including Inachus and Macropodia ; the Maiinæ, to which Maia belongs; and the Pisinæ, in which group are usually placed Pisa and Hyas. From the existing descriptions of the larval forms of these last it seems very unlikely that they ought to be placed so close together, for the larva of Pisa, according to Cano's (1893) description, is much more like the Inachinæ, and that of Hyas, according to Williamson's description (op. cit.), more like Maia, although quite distinct and easily separated. Eurynome aspera is usually placed in the Parthenopidæ. Its larval form, however, does not agree with those of other members of the family described by Cano.

Claus (1876) gives a good drawing of the first zoea of Inachus Dorsettensis (as I. scorpio), also Cano (op. cit.). Nothing further is known of the 
larval forms of this species which are described in this paper. Williamson (1915), under the name of Megalopa niga nov. spec. describes and figures a megalopa, obviously an Inachus. Gourret (1884) figures the larva of Inachus Dorynchus, evidently the pre-zoea without its cuticle but not yet in the zoeal stage. Macropodia longirostris is so far not known in its larval stages, and is described here for the first time. The larval stages of $M$. Egyptia are not known, but M. rostratus (as Stenorhynchus phalangium) is figured and described by Cano (op. cit.) in the first zoea, megalopa, and first crab stage. He also gives drawings of the pre-zoeal telson and antenna, details of the carapace, and some of the appendages of the other stages. He does not, however, describe the second zoea, not having seen it either in Macropodia or Inachus. Lo Bianco (1904) figures the first crab stage of this species, as the megalopa, which is noted by Williamson. J. V. Thompson (1836) figured its early larva (as Macropodia phalangium) before it reached the zoea stage. His figure of the megalopa reproduced (1915, p. 533) and named by Williamson " Inachus rostratus (L.) (?) or either Macropodia phalangium or dorsettensis," is more likely to be Hyas, already noted by Cano, as it has setose fifth pleopods and more than six abdominal segments. Achous Cranchii has not been described in the larval state, although the large eggs are known. Cano (op. cit.) describes and figures the zoea of Pisa. Gourret (op. cit.) also figures it, but his drawing is entirely different from Cano's and so much resembles the zoea of a Pinnotheres common in the plankton at Plymouth (probably $P$. veterum) that one cannot help wondering whether by any chance the larvæ have got mixed, especially as Gourret also figures the telson of Pinnotheres veterum. Hyas araneus has been well worked out by Williamson $(1900,1915)$, and a good deal is described of the larval stages of $H$. coarcticus by Stephensen (1912) and Williamson. They are easily recognisable by their prickly carapace spines and in the megalopa by the three-spined rostrum and conspicuous dorsal spine. Maia squinado was known in the pre-zoeal stage by Couch (1843), who is quoted by Bell (1853). Schlegel (1911) succeeded in rearing this species at Roscoff from egg to crab, but unfortunately gives no description of his methods nor any figures of the larvæ. Cano (op. cit.) describes the life history of its relative Maia verrucosa from the Mediterranean from egg to crab and gives good figures. Claus (op. cit.) gives a drawing of the first zoea of the same species which might equally well do for Maia squinado. In this, however, he omits the lateral spines of the carapace. Eurynome aspera is figured by Kinahan (1857) in the pre-zoea and by Cano (op. cit.) in the first zoeal stage. Gurney (1924) also gives an account of these stages. In the present paper all the larval stages from egg to crab are described for the first time in Inachus Dorsettensis (the first zoea only being previously described) and Macropodia longirostris, 
and figured for the first time in Maia squinado. All of these were reared in the Laboratory from egg to megalopa, the crab stages being reared from late zoeæ and megalopæ from the plankton.

\section{Method of Rearing.}

A successful method has been found by which the larvæ of several crabs have been reared through different stages. So far the megalopa has not been successfully brought to the crab stage, but it is hoped soon to succeed in this also. The method adopted was to place the berried crab in an aquarium-plunger jar, aërated jar or in running water. In the first two cases the crabs were left until the eggs hatched; in the last case the water was turned off or the crab transferred to a plunger jar or aërated jar just before the eggs were hatched. The newly hatched larvæ were then transferred to various receptacles, plunger jars, aërated jars, or small glass dishes, filled with water from outside the Breakwater, in which had been placed special food. A selection of diatoms from the very fine tow-nets or a culture of Nitzschia were not satisfactory as food. Evidently something more substantial was necessary. Miscellaneous plankton containing chiefly small copepods was also not suitable, probably because much of it died and sank to the bottom of the jar without being eaten. Finally, oyster larvæ from the oyster itself were tried, and this proved very successful. I am indebted to Mr. O. D. Hunt for suggesting mollusc eggs as food, and to Dr. J. H. Orton for the regular supply of oyster larvæ. With a diet of oyster larvæ Maia squinado and Inachus Dorsettensis were brought to the megalopa stage. Sometimes the megalopæ were transferred to other vessels and fed on small crustacea or pieces of mussel, but in no case did one turn into a crab. That the crab larvæ really ate the oyster larvæ was apparent by examining the stomachs and intestines, which contained remains of the shells.

The oyster larvæ were washed out of the parent oysters and pipetted into the jar containing the crab larvæ. Here they swam about and could be seen scattered throughout the jar. For several days this might last and when the water was clear again a fresh supply was put in.

As the spawning season of the oyster finished in October it was necessary to find other food. At the suggestion of Dr. C. M. Yonge, who kindly gave the wood in which the molluses were found, Teredo larvæ were tried. Artificial fertilisations were made and the one-day-old larvæ given to the crab larvæ as food. It is extremely easy to make fertilisations of Teredo, the eggs of one female and a small sample of sperm from a male serving for food for several days. The eggs, which are opaque and colourless, are washed out from a female and pipetted into glass bowls containing clean sea-water, and sperm added. In a few hours activity is shown, and 
by the next day larvæ with shells are present and can be used for food. The wood with Teredo had been in a tank in the Laboratory for some months, but still contained the ripe molluses. Maia squinado and Inachus Dorsettensis were again reared to the megalopa on this, and in addition Macropodia longirostris.

Another satisfactory food was found to be the larvæ of the tube-building annelid Pomatoceros. This is useful as it breeds all the year round, but more specimens must be used in order to obtain enough food. About six ripe females serve for two bowls of food. The purple eggs which are easy to see are washed out from the female, after having crushed the tube and extracted the worm, put into a bowl of clean sea-water and sperm added. The larvæ are moving in a few hours, and by the next morning are small trochospheres ready to be given as food.

These three larval forms are thus found to be excellent food for larval crabs. The aquarium is quite clean, as the food is eaten before it can die, and it is evident that larval crabs thrive on a diet of small moving living animals, which is apparently preferred to plants. The usual size of the food is the following :-

$\begin{array}{lcccc}\text { Oyster larvæ } & . & . & . & 0.17-0.18 \mathrm{~mm} \text {. across. } \\ \text { Teredo larvæ } & . & . & . & 0.05-0.06 \mathrm{~mm} \text {. across. } \\ \text { Pomatoceros larvæ } & . & . & 0.08 \mathrm{~mm} \text {. across. }\end{array}$

On Teredo and Pomatoceros Macropodia longirostris was reared as far as the megalopa, which, as well as the last zoea, also ate other crab larvæ. The zoea ate the first zoea of Portunus depurator and the megalopa ate this also, besides the first zoea of Inachus Dorsettensis. These were caught when perfectly lively, the megalopa swimming all the time and clinging to its prey with its legs (Plate III, Fig. 4). The first zoea of Inachus Dorsettensis also ate the eggs of Carcinus monas.

Besides these three crabs, which have been reared as far as the megalopa, others have been brought as far as the last zoeæ, and many zoeæ from the plankton have been reared through crab stages. A description of these is deferred until more complete.

\section{The Larval Stages of the Brachygnatha.}

It is easy to distinguish a typical zoea of a spider crab (Oxyrhyncha) from a typical zoea of an ordinary crab (Brachyrhyncha). Judging by the British species and any foreign species which have been described, the zoeæ differ in the following particulars (excepting a few forms which from their habit make special modifications necessary) :-

Brachyrhyncha. More than two and frequently five stages, the first 
and second, with only a slight or without any trace of pleopods, the antenna without, or with only a trace of, a flagellum.

Oxyrhyncha. Only two zoea stages, the pleopods showing in the first zoea and underneath the pre-zoeal skin, the antenna with a flagellum. Certain members of the Parthenopidæ are probably exceptional in having more zoeal stages and an early zoea like the Brachyrhyncha. In the following notes on the Oxyrhyncha the Parthenopidæ are excepted. As far as one can tell from any exact descriptions and individual observations the megalopæ of the two groups seem to be differentiated by the presence of long feelers on the last leg in the typical Brachyrhyncha (except the Pinnotheridæ, which are exceptional in their habit) and their absence in the Oxyrhyncha. Ebalia belonging to the Oxystomata is also without them.

Excepting the Dromiacea, which very possibly should not be included in the Brachyura at all, the brachyuran zoea is flattened from side to side and has two pair of maxillipedes developed as swimming organs, the third pair being quite rudimentary in all the zoeal stages. On the extremities of these swimming maxillipedes are long setæ, which are very regular, and we are able to recognise the different zoeal stages from the number of setæ on the maxillipedes. Thus the first zoea always has four setæ. This I believe is without exception, unless the zoea is abnormal. The second zoea has six, although five are sometimes present; never, I think, have more than six been observed. Here the ordinary Oxyrhynchan zoea stops, therefore a zoea with more than six spines on the maxillipedes almost certainly does not belong to the typical Oxyrhyncha. The zoeæ of the Brachyrhyncha and some at least of the Oxystomata (Ebalia) have eight setæ at the third stage, later stages, if present, having ten at the fourth, and usually twelve at the fifth. There may, however, be one less on one or both maxillipedes and it is possible that the fifth zoea may have only ten (Hyman, 1920, in Gelasimus). Thus all the species of Portunus seem to have five zoeal stages; Carcinus, Pilumnus, and Gonoplax, four. It is interesting, however, to find that in certain species of the Pinnotheridæ the second zoea with six setæ on the maxillipedes and conspicuous pleopods is the last, and changes into a crab-like megalopa. This is found to be the case at Plymouth with a zoea, which is probably Pinnotheres veterum, but Hyman (1924) thinks it probable that there are more than two zoeal stages in some species.

As far as British crabs go the above differentiating characters appear to hold good between the Oxyrhyncha and Brachyrhyncha except in Pinnotheres, which on account of its habit has an abbreviated life history.

From the egg of all Brachygnatha known issues a pre-zoea. That is to say, the zoea enclosed in an extremely thin embryonic cuticle, which 
has no segmentation, and bears very long and broad setose spines on the antennules, antennæ, and telson. This embryonic cuticle is considered by Gurney (1926) to bear metanaupliar characters, the first zoea corresponding to the protozoea of the penaeids. It is difficult to discuss such a question with crabs, because the zoea has become so complicated by specialisation that it has characters of both early and late stages together. In the present notes the stage bearing the embryonic cuticle is called the pre-zoea, the stages following being the first zoea, second zoea, and so on until the last zoea changes to the megalopa. The chief character of the Brachygnathan zoea being its possession of two pairs of maxillipedes functioning as swimming organs, the remaining thoracic appendages being rudimentary, and its laterally compressed body. The telson tends to be forked and is truly forked in all typical forms. The megalopa is characterised by its free swimming pleopods, the body being flattened dorsoventrally and all the legs functional. The abdomen is usually held straight out, while the pleopods act as swimming organs. The megalopa changes to a crab with the abdomen tucked in under the body, and the pleopods, usually much reduced, no longer serving as swimming organs.

The pre-zoea may cast off its embryonic cuticle at once, or it may keep it for several hours. In the case of all the three crabs here described it is retained for several hours and the little larva swims actively. Its movement is, however, a peculiar one, for it is hampered by the cuticle, possesses no dorsal spine, and the maxillipedes are enclosed in simple sheaths without setæ although free from the body. The chief movement is a bending inwards to the body and out again of the abdomen. The large flat spines on the antennules, antennæ, and telson, by spreading out apparently help in keeping it up. The whole movement is a jerky one and lacks restraint, its object probably being entirely the casting of the cuticle. In all the pre-zoeæ known there are seven spines on each side of the telson, six of them usually setose and very long, and one, the fourth from the side, being shorter and non-setose covering the spine which will form the point of the fork in the zoea. On the antennule there are usually two long setose spines, one larger than the other, and on the antenna three or four long setose spines.

The pre-zoea of Maia squinado, Inachus Dorsettensis, and Macropodia longirostris, differs little in each species except in size and colour, due to the zoea which it covers. In Maia it is an olive-green, in Inachus and Macropodia yellow and orange, thus making the general appearance totally different. The pre-zoeæ of Inachus and Macropodia are very much alike both in colouring and structure.

The zoea of Maia and the zoeæ of Inachus and Macropodia differ very much, representing as they do two very distinct sub-families of the Maiidæ. In the sub-family Inachinæ the zoea has no rostral spine nor 
lateral spines on the carapace, only the dorsal being present, the second zoea has only six segments in the abdomen and only four pairs of pleopods, and the megalopa is also destitute of the last segment of the abdomen which is fused with the telson, and has only four pairs of setose pleopods, the fifth pair being represented by the tiniest of rudimentary buds. In the Maiinæ, however, there is a rostral as well as lateral spines to the carapace besides the dorsal, and there are the usual seven abdominal segments and five pairs of pleopods. The first zoea in all three has rudiments of pleopods, in Inachus and Macropodia on the second, third, fourth, and fifth abdominal segments, and in Maia on the second, third, fourth, fifth, and sixth, although the sixth is not yet cut off from the telson. In the second zoea the pleopods are well developed with two branches, one long and one very short, the sixth abdominal segment in Maia being now separated from the telson.

Here it may be noted that in the larval forms there are no pleopods on the first abdominal segment. If they are normally present in the crab they are developed in later stages. It thus comes about that the fifth pleopods of larval crabs borne on the sixth abdominal segment correspond with the uropods of Crustacea such as the shrimp, but they are not differentiated from the others to form a tail fin. It often happens, however, that the number of setæ on these differs from those on the other pleopods, and this may be used as a good distinguishing character in many species. In most of the adult crabs the first pair of pleopods borne on the first abdominal segment appears later, and only the first and second are usually present in the adult male. I have found that they appear in the second crab stage of Corystes reared from the zoea in the laboratory. In the female the first pleopods are usually absent as in the larva. The second to the fifth pleopods are used for holding the eggs until hatched. The uropods (sixth abdominal appendages) are absent in all typical crabs, therefore these present in the megalopa usually abort, having already aborted in those crabs in which the sixth segment is fused with the telson (e.g. Inachinæ).

In the first zoea of all the typical Oxyrhyncha the antenna has three branches, two long and more or less spiny representing the exopodite and the spinous process, and a short soft process without spines, which forms the flagellum (Plate IV, Fig. 12). This last is the endopodite. The Oxyrhyncha thus differ from the typical Brachyryncha where the flagellum is not present or only extremely indistinct, in the first and often in the second zoea, and only appears at any length in the later stages. In the second zoea of the Oxyrhyncha the flagellum is fairly long. In the megalopa and crab stages only the endopodite persists at any length, although a small process may represent the exopodite (Plate IV, Figs. 4, 8, 14). In the three crabs described Maia differs from the 
other two in having the exopodite much shorter than the spinous process in both zoeal stages, whereas they are of nearly equal length in Inachus and Macropodia, - a fact noticed by Cano for Maia verrucosa.

The antennules, mandibles, maxillæ, and maxillipedes, do not differ much in the three species, and the remaining legs are all present although rudimentary. In the second zoea the appendages are remarkably backward in development, and the antennules and legs still unjointed whilst there is as yet no palp to the mandible. The megalopa and crab stages are easily distinguishable in all three species.

A description of the larval stages of these three crabs is given below. Specimens of all the zoea and megalopa stages were procured from the plankton and compared with the reared forms. These were kept until they cast their skins, and in all cases the numbers of larval stages and their structure were exactly like those which were reared. In all these there were found to be two zoeal stages and one megalopa, the megalopa changing into the young crab.

\section{OXYRHYNCHA.}

\section{MAIIDE.}

INACHINA.

\section{Genus Inachus.}

Inachus Dorsettensis (Pennant) is perhaps the commonest of all the Spider Crabs in the Plymouth district, living on the sea bottom from beyond the Breakwater on almost all the dredging and trawling grounds. It is trawled abundantly by the Salpa in Plymouth waters, and breeds all the year round. Berried females are found from January to December, and so also are the larval stages in the plankton. In 1926 a maximum of these larval stages was noted in November, but large numbers may be seen in any other month. The eggs are reddish orange when first extruded and remain hidden in the pouch until they are nearly ready to hatch, when the colour changes to a dull pale yellowish brown and the pouch opens slightly as the eggs occupy more space. The orange-red colour is due to the yolk, which disappears when the larva is ready to hatch. The eggs certainly take some weeks to hatch, probably some months, and enlarge considerably, being nearly twice the original size when ready to hatch. Breadth of early stage, $0.48 \mathrm{~mm}$. ; late stage, $0.72 \mathrm{~mm}$. When one batch of eggs has been hatched another frequently takes its place, but these have not been hatched out in the Laboratory. 
The berried female was placed in a plunger jar, and the eggs hatched out, when the larvæ were transferred to a fresh plunger jar, aërated aquarium and small glass dishes. All these were fed on fresh oyster larvæ and throve well. The pre-zoea moved about for some hours but did not feed, soon cast its cuticle, and the first zoea appeared.

The following dates show the length of time taken for changing into the different stages. These are quite typical, other batches being much the same :-Pre-zoea to first zoea, $21 / 7 / 26$; changed to second zoea, $26 / 7 / 26$; changed to megalopa, $6 / 8 / 26$. If the aquarium was not congenial it might take longer. Young crabs from the megalopa procured from the plankton took various times to change, from about a fortnight to more than a month. These were placed separately in small glass dishes and fed on small bits of mussel. If more than one were put into any dish the stronger specimen would invariably eat the weaker until only one was left.

The colour is the same from pre-zoea to last zoea. These have a yellowish appearance, the body being pale yellow almost all over, the colour, however, not reaching the greater part of the dorsal spine nor the spines and tips of the antennules, antennæ, maxillipedes, and telson. The eye is a deep blackish brown with a superficial splashing of yellow, and the yellow tends to become orange in the region of the stomach. Bright orange chromatophores occur at the base of the dorsal spine posteriorly, the side of the first abdominal segment between the eyes, on the mandible, above the maxillipedes and on the second maxillipede, and a diffuse pinkish tinge is to be found round the fore part of the body under the carapace. Blackish brown chromatophores are present with the red pigment at the base of the spine, between the eyes and, separately on the carapace and ventrally on the abdominal segments two to five and at the base of the telson. This general scheme of colour may be intensified or the reverse by changes in the chromatophores, some even tending to disappear, so that it is not possible to lay down any hard and fast rule. The main colour is pale yellowish with pink in parts with orange-red and black spots, the most conspicuous of the red spots being at the sides of the first abdominal segment.

The pre-zoea (Plate I, Fig. 1) first hatched in March, others hatched at intervals until November. About $1.9 \mathrm{~mm} *^{*}$ in length. It is, however, difficult to measure accurately, as when alive it is rarely straight and when dead it contracts immediately. The cuticle encloses the first zoea ; dorsal spine of the carapace folded down and retracted underneath; first and second maxillipedes free from the body but enclosed in sheaths

* All measurements of the body length are taken from the front of the head to the tip of the telson fork (in the pre-zoea exclusive of embryonic spines). Spines are measured from base to tip. 
with the terminal setæ retracted. Antennule (Plate I, Fig. 4) provided with two long spiny setæ, very flat, one about a third longer than the other and altogether stouter. Antenna (Plate I, Fig. 5) with four long spines coming from the same base enclosing the exopodite; flagellum and spinous process enclosed in separate simple sheaths. Telson (Plate I, Fig. 6) provided with the usual seven spines each side, six long and setose, the fourth from the side non-setose and short enclosing the terminal spine of the fork of the zoea.

Having cast the embryonic cuticle after several hours the first zoea appears.

The first zoea (Plate I, Fig. 7), about $2.4 \mathrm{~mm}$. in length. Dorsal spine, $0.72 \mathrm{~mm}$., curved gently backwards, no rostral nor lateral spines on the carapace. Midway between the dorsal spine and the front of the head is a slight protuberance. Eyes large, and sessile; antennule uniramous with two æsthetes and two spines; antenna with spinous process and exopodite very long; spinous process $0.64 \mathrm{~mm}$. in length ; exopodite hardly so long; both spiny at the tips, exopodite with two large spines slightly behind the centre. Flagellum (endopodite) unjointed, between the two processes, about $0.16 \mathrm{~mm}$. in length. Mandibles bilobed and heavy with thick teeth; first and second maxillæ of the usual type. First and second maxillipedes armed with four long setose spines, the first with a five-jointed endopodite, the second with one three-jointed. Third maxillipede bilobed, but quite rudimentary and bearing a gill. First leg chelate, but also rudimentary with a gill; remaining legs only long buds, the second and third with gills. Pleopods show as small buds on the second to the fifth abdominal segments. Carapace bordered postero-laterally with small spines. Abdominal segments each with a couple of hairs dorsally, the second with a hooked spine on each side, and the third to the fifth with a long spine posteriorly each side. There are six abdominal segments, including the telson which has long forks with one large spine laterally on the outer margin each side and six setose spines inside the fork. Very minute spicules round the points of the fork.

The second zoea (Plate II, Fig. 1), much like the first but easily recognisable by its long pleopods, six setæ on the maxillipedes, and stalked eyes. Only slightly larger than the first, about $2.9 \mathrm{~mm}$. in length. Dorsal spine smaller, $0.64 \mathrm{~mm}$. in length. Antennules and antennæ have progressed little. Antennule unsegmented; antennal flagellum longer, although still unsegmented. Mandibles (Plate II, Fig. 4) with no palp; maxillæ and maxillipedes have progressed in the usual way. Legs still unsegmented, but larger and pleopods long, otherwise the abdomen has altered little, there being still only six segments including the telson, the latter having hardly altered at all. 
The megalopa (Plate III, Fig. 1), which comes from the second zoea, has a peculiar feature, characteristic of both the British species of Inachus and probably generic, in the bicornuate rostrum. Body, $1.6 \mathrm{~mm}$. in length, yellowish with brownish splashes and some red and black chromatophores. In common with all the larval Oxyrhyncha known the second to the fifth walking legs have slender pointed tips. In common with Macropodia, Inachus has the sixth abdominal segment fused with the telson throughout its life, and thus the megalopa of Inachus Dorsettensis still has only six abdominal segments and it has only four pairs of pleopods, the second to the fifth, the sixth pair being represented by the faintest buds. It swims about vigorously by means of its setose pleopods, the maxillipedes now being entirely used for eating purposes. Carapace with rostrum sticking straight out composed of two lateral pointed horns and on the dorsal surface several more or less pointed spinous processes, notably two behind the eyes, one just behind them in the centre, and three posteriorly. Eyes with fairly long stalks, antennule with a two-jointed base and two simple branches, the longer bearing a bunch of æsthetes, antennæ consisting of a base and the jointed endopodite with a blunt short stump representing the exopodite; spinous process completely disappeared; mandible has a small palp. Maxillæ and maxillipedes now of the usual crab structure, the third maxillipedes being completely formed; first legs chelate, remaining four with long and pointed extremities with fine spicules at the tips and all these legs are crab-like. First abdominal segment with no trace of pleopods, the second to the fifth bearing pleopods consisting of a large outer setose and small inner simple branch, each setose branch with eight setæ. Telson squarish with rounded edges. At the posterior dorsal edges of the first abdominal segment are two hairs, on the second segment two hairs and a pair of long lateral spines, on the third two hairs and two long spines outside them, on the fourth and fifth two long spines laterally, two dorsal spines and two pairs of hairs, and on the second is a median spine dorsally (Plate II, Fig. 10).

The megalopa changes into the first crab stage, $0.96 \mathrm{~mm}$. across the carapace, with a bicornuate rostrum $0.16 \mathrm{~mm}$. in length. Directly the young crab emerges it tries to find something with which to dress up, and is wonderfully successful in making itself as inconspicuous as possible by means of pieces of weed and debris placed on the curved spines and hairs which are present all over its body and legs. Eyes with long stalks ; carapace with several protuberances. Legs long. Altogether the crab has a characteristic appearance easily recognisable, and, after two more moults, $1.28 \mathrm{~mm}$. and $2 \mathrm{~mm}$. respectively across the carapace, the young crab has the usual distinctive character in the four knobs on the carapace behind the eyes. The tips of the fourth and fifth walking legs have two 
blunt thorn-like teeth, which distinguish them from Macropodia which has more than two and not so large. Unfortunately the young crab nearly always devoured most of the cast skin, so that it was not possible to make a drawing of the whole of it.

The only other species of Inachus in the Plymouth district is Inachus Dorynchus. This has also been reared in the Laboratory from the egg to the second and last zoea, but not as yet to the megalopa, which has, however, been found in the plankton and kept until it changed into the young crab. The stages in $I$. Dorynchus are very like $I$. Dorsettensis with certain distinguishing marks, notably the larger size. The two species both have the outstanding features which they share with Macropodia in the absence of rostral and lateral spines in the carapace in the zoea, and the sixth segment fused with the telson in all late stages. The zoea of Inachus can be distinguished from Macropodia by the very large lateral spine on the telson which is much smaller in Macropodia, the megalopa and young stages being easily recognised by their rostra.

\section{Genus Macropodia.}

Macropodia longirostris (Fabricius) is very nearly as common as Inachus Dorsettensis, occurring in the same situation and also breeding all the year round. The eggs are borne in the same way and are of the same colour, changing from reddish orange to a dull pale yellow and also increasing in size. Early eggs $0.55 \mathrm{~mm}$. across, later eggs $0.6 \mathrm{~mm}$. They take some weeks, possibly some months, to hatch, and as in Inachus when one batch is hatched another may take its place at once.

The eggs were hatched in the same way as Inachus, and the newly hatched larvæ separated into various vessels. Most of them were fed on Teredo larvæ, some on Pomatoceros, and others on oyster larvæ, the latter food giving out before rearing was complete. Some first zoeæ of Portunus depurator were placed in some of these vessels, and were certainly eaten by the second zoea and megalopa if not by the first. The first zoea of Inachus Dorsettensis was also eaten by the megalopa.

The following dates show about the usual time taken for reaching the megalopa stage:- Pre-zoea and first zoea hatched 6/10/26, second zoea from first 14/10/26, megalopa from second 4/11/26. This is probably a longer time than is natural for the second zoea to change to megalopa, judging from Inachus and Maia.

The pre-zoea (Plate I, Fig. 2), about $2.4 \mathrm{~mm}$. in length, when hatched from the egg moved actively for some hours in the same way as Inachus, finally getting rid of its embryonic cuticle and emerging as the first zoea. In colouring it is extremely like Inachus, diffuse yellow with red and black, the red being specially conspicuous on the sides of the first ab- 
dominal segment. In shape it is also very similar to Inachus Dorsettensis, a difference being seen in the telson under the cuticle, the lateral spine being much smaller than in Inachus. The embryonic spines on the antennules and telson are shorter than in Inachus.

The first zoea (Plate I, Fig. 8) is also very like Inachus at a first glance, and they have many features in common. The difference in colour is slight, but Macropodia seems to be somewhat darker. The length of the first zoea is about $2.7 \mathrm{~mm}$., dorsal spine is longer than in Inachus, measuring $0.96 \mathrm{~mm}$. in length; telson also longer. The edge of the carapace has small spines ventro-laterally, and has two hairs dorsally behind the spine. Antennule with two æsthetes and a short spine; antenna with a long spiny exopodite, a spinous process of about the same length and a short flagellum. Mandibles, maxillæ, and first and second maxillipedes are of the usual type, the third maxillipedes and legs being present but rudimentary. Pleopods show as small buds from the second to the fifth segment. On each of the abdominal segments are a couple of small hairs dorsally. On the second segment is a lateral knob each side, and laterally on the third to the fifth segment are long pointed spines. Telson with one lateral spine, which is much smaller than in Inachus, and six setose spines inside the fork.

The second zoea (Plate II, Fig. 2), about $3 \mathrm{~mm}$. in length. Six, rarely five, spines to the first and second maxillipedes; eyes stalked. Dorsal spine about the same length or rather shorter than in the first zoea. Antennule unjointed with five æsthetes, one very long and curved, and a spine; flagellum of antenna long and faintly jointed. Mandible with no palp, maxillæ and maxillipedes have progressed in the usual way, the third maxillipedes being quite rudimentary but bilobed, the first leg large and chelate and the remaining legs long and pointed. None of the legs are truly segmented. Abdominal segments still five plus the telson, and each bears dorsally a pair of hairs. Second segment with a curved knob on each side and postero-laterally a very small spine, third to the fifth each bearing laterally a short and a long spine. Second to the fifth segment with long pleopods, each composed of a long and short ramus, the long one bearing eight setæ. Telson almost exactly the same as in the first zoea.

The Megalopa (Plate III, Fig. 2), $2 \mathrm{~mm}$. to $2 \cdot 3 \mathrm{~mm}$. in length, the width across with legs outstretched but slightly bent, about $4.8 \mathrm{~mm}$. It has a habit, common in the group, of folding its legs tightly against the body while swimming with its abdomen outstretched. It is conspicuously speckled with chestnut brown, and has a brownish orange appearance when seen with the naked eye. It may be watched catching the zoea of Inachus, making a cage with its legs for it whilst it swims by means of its pleopods; finally tearing it to pieces and extracting the soft parts 
(Plate III, Fig. 4). The megalopa of Macropodia longirostris (and the other known species of the genus) differs from that of Inachus in its smoothness and much less prominent armature of the abdomen; but, on the other hand, the prominences on the carapace are much more conspicuous and project as long blunt spines; particularly those behind the eyes and one in the centre. The rostrum is bent down so that the dorsal outline is nearly straight, the bend making the two sides somewhat thickened, so that on tilting the carapace slightly backward it may look three-lobed, a character emphasized in its near relative, Macropodia rostrata. Abdomen with two hairs at the posterior dorsal margin of each segment; telson rounded and the four pairs of pleopods each with eight setæ as in Inachus, there being a small inner non-setose lobe to each; fifth pair of pleopods represented by two minute protuberances behind at the base of the telson. Antennule jointed, bearing a bunch of æsthetes ; antenna consists now of the usual endopodite with the remains of the exopodite as a blunt process. Small palp on the mandible and maxillæ and maxillipedes formed entirely for eating purposes. Legs fully formed, the first strongly chelate, the second to the fifth, ending in slender points with minute spicules. None of the reared megalopæ reached a crab stage, but specimens from the plankton were easily kept alive until they changed into young crabs.

The first young stage (Plate III, Fig. 5) is remarkably large to come from the megalopa, the legs having a stretch of several times the breadth of the body. The rostrum is bilobed, each lobe being squarish with three lateral prominences, and, as well as the body and legs, armed with long curled hairs. Like Inachus it immediately covers its body with any weed or debris that it can find and soon succeeds in hiding itself. First crab stage $1.28 \mathrm{~mm}$. across the broadest part of the carapace; legs with a stretch of over a centimetre. The two hind legs are armed with seven or eight, usually seven, strong thorn-like teeth. Carapace with two prominent knobs behind the eyes and two behind in a straight line, one almost central, the other posterior. Abdomen tucked in under the body, and pleopods much reduced.

Of the other two species of Macropodia in the Plymouth district one, Macropodia rostratus, has been hatched from the egg and the pre-zoea and first zoea procured, the latter corresponding very well with Cano's figure (op. cit.). The second zoea was found in the plankton (differing from $M$. longirostris in the long dorsal spine and very long branches to the antennæ), and kept until it changed to the megalopa. This (the megalopa) again agrees well with Cano's figure (differing from $M$. longirostris in its rostrum, which is conspicuously three-lobed). A young crab which emerged from the megalopa out of the plankton also agreed with Cano's figure and that of Lo Bianco (op. cit.). This young crab differs 
from $M$. longirostris in the shape of its rostrum and numbers of thornlike teeth on the extremities of the two last legs, but above all by its much smaller size and stretch of legs. Another megalopa from the plankton gave rise to a third form of Macropodia, almost certainly $M$. Egyptia, intermediate in size between $M$. longirostris and $M$. rostratus, with a differently shaped rostrum and different terminal joints to the two last legs.

\section{MAIIN Æ.}

\section{Genus Maia.}

Maia squinado (Herbst) has been already reared by Schlegel (1911) as far as the first young stage, but as he gives no figures it is certainly worth while figuring and re-describing the larvæ of this well-known species.

This large Spider Crab is extremely common in the Plymouth district and abundantly present in the trawl. Its chief breeding season appears to be from July to September, although berried crabs may be taken occasionally earlier or later. They are recorded from March to June in the Plymouth Invertebrate Fauna (1904). The first brought to me in 1926 was in July and the last was in September. From July to October the larvæ were present in the plankton, chiefly first and second zoea with an occasional megalopa. In November all the female crabs brought in had shed their eggs. Schlegel states that the extended eggs are carried for at least six months. They are at first bright orange-red and hidden by the large abdomen, but as they get older they become nearly black and much larger, forcing out the abdomen so that they can be seen projecting from the body. Early eggs, $0.64 \mathrm{~mm}$; late eggs, $0.72 \mathrm{~mm}$. The berried female with eggs nearly ready to hatch was kept in a tank with running sea-water. When the pre-zoea was about to emerge the water was turned off and the larvæ swarmed upwards towards the light, and could be drawn off with a pipette and placed in various vessels. As with Inachus and Macropodia the larvæ were only reared as far as the megalopa, but the last zoea from the plankton was reared over three crab stages.

The larvæ of Maia as representing the Maiinæ differ much from Inachus and Macropodia, which represent Inachinæ. In common they have only two zoeal stages and consequently have advanced larvæ, the megalopa having pointed tips to the legs, two to five; but they differ in that the zoea of Maiae has lateral and rostral spines on the carapace, as well as a dorsal, and the telson has three lateral spines, whereas Inachus 
and Macropodia have only the dorsal spine on the carapace and one lateral spine on the telson.

The colour of the larvæ of Maia is very characteristic, being a dark greenish brown with chromatophores of yellow and black covering the body. The zoeæ were reared on Oyster, Teredo, and Pomatoceros larvæ, the megalopa and crabs on bits of mussel. It is somewhat remarkable that although the zoeal stages are fairly large the actual crab emerging from the megalopa is extremely small, very much smaller than some of the crabs which in the adult stage are of a much smaller size than Maia.

The following dates show typical times for the different larval stages :-

Pre-zoea and first zoea hatched $11 / 8 / 26$; changed into second zoea, $16 / 8 / 26$; changed into megalopa, 20/8/26.

The eggs hatch out as pre-zoeæ, which remain active for several hours and move in the usual way, finally getting rid of the embryonic cuticle and emerging as first zoeæ.

The pre-zoea (Plate I, Fig. 3), about $2.5 \mathrm{~mm}$. in length. Very large eyes and long embryonic spines of the same number and character as those of Inachus and Macropodia, and resembles these forms closely.

The first zoea (Plate I, Fig. 9), about $2.9 \mathrm{~mm}$. in length; backwardly curved dorsal spine, lateral spines and a rostral spine, all short. The form of this zoea is characteristic and unmistakable in the Plymouth plankton. Pleopods present as distinct buds on the abdominal segments 2 to 5 , all of which as well as the first have small lateral spines increasing in size to the fifth. Sixth segment not yet separated from the telson. Postero-lateral edge of carapace with a few long hairs, but the margin not toothed. Colour a general olive-green, composed of a yellowish green ground with black chromatophores at the posterior base of the dorsal spine, in front of the head, in the mouth parts, on the basipodites of the maxillipedes, and on the lateral portion of the carapace extending along the intestine for about a quarter of its length, and black chromatophores ventrally on all the abdominal segments as far as the fifth. Telson and spines of the carapace colourless. The same colour is continued in the second zoea and megalopa. No trace of red in any stage.

Antennule with three æsthetes; antenna with a fairly long serrated spine, an exopodite about half its length bearing three spines terminally, and an unjointed flagellum (endopodite) not quite so long as the exopodite. Thus the antenna differs much from Inachus and Macropodia where the exopodite is almost the same length as the spinous process. Mandibles, maxillæ, and maxillipedes of the usual form, the first and second maxillipedes with four long setæ, the third rudimentary and small. Legs all present, but rudimentary. Each abdominal segment with a pair of small hairs dorsally and posteriorly. Telson peculiarly straight and not spread 
out. Laterally it bears three spines, the most anterior being the largest. Six spines internally to the fork.

The second zoea (Plate II, Fig. 3) not much bigger than the first, about $3 \mathrm{~mm}$. in length. It has now seven abdominal segments including the telson and five pairs of pleopods on the second to the sixth segments, all long except the fifth pair, which are still buds. Dorsal spine shorter; eyes stalked. Antennule unjointed; antennal flagellum longer but unjointed, and mandible without palp. First and second maxillipedes with six setæ (rarely five). Third maxillipede and legs, although larger, quite rudimentary and unjointed. Telson hardly altered. The second zoea is thus in a backward state compared with its relative $M$. verrucosa, described by Cano, although it is the last zoea, and changes into a megalopa.

The megalopa (Plate III, Fig. 3), rather long for its breadth with the same characteristic colouring as the zoea, $2 \cdot 4 \mathrm{~mm}$. in length, with a long carapace measuring $1.4 \mathrm{~mm}$. The legs rather short. Carapace with no spines but many protuberances, rostrum bent down and indented laterally, giving the appearance of the three teeth described by Schlegel. Tips of second to fifth legs pointed and armed with short spines, not with only minute spicules as in Inachus and Macropodia. Seven abdominal segments including the telson, which is nearly square, the last pleopods (sixth abdominal appendages and fifth pleopods) bearing five setæ, the others eight. Antennule with a base of two joints and two short branches, one ending in a bunch of æsthetes. Antenna has lost both exopodite and spinous process; endopodite jointed in the usual way. A very faint prominence represents all that is left of the exopodite. Mandible with a small but distinct palp.

The megalopa obtained from the plankton turned into a crab, and this lived as far as three young stages.

The first crab stage is exceedingly. small, only $1.28 \mathrm{~mm}$. across the carapace (Plate III, Fig. 10), of a roundish shape, with compact rather short legs and a pale brownish colour. Five lateral marginal spines on the carapace and a pointed rostrum with a crenulated margin. This does not agree with Schlegel's description, who says it is in all respects like the adult, for even in the third young stage the rostrum is not bifurcate.

The second crab stage, $1.9 \mathrm{~mm}$. across the carapace, the third $2.5 \mathrm{~mm}$. across. From the first the small crab seeks to cover itself with extraneous matter and usually is completely hidden.

Comparison of Larval Stages of I. Dorsettensis, M. Longirostris, AND M. SQUINADO.

We can now compare the three crabs representing three distinct genera and two distinct sub-families. 
All three agree in having far advanced larvæ, only two zoeal stages and one megalopa before the crab stage is reached, and because of this the first zoea already shows pleopods and antennal flagellum and far advanced rudiments of the legs. There are no feelers on the extremity of the last leg of the megalopa. The representatives of the two subfamilies differ in the number of abdominal segments in the second zoea, megalopa, and crab, there being the usual seven in Maia and only six in Inachus and Macropodia, and in consequence there are five pair of pleopods in Maia and only four in Inachus and Macropodia (the fifth pair occurring in these as the tiniest buds). The carapace differs in there being dorsal, rostral, and lateral spines in the zoea of Maia and only a dorsal spine in Inachus and Macropodia, and the telson differs in having three lateral spines in Maia and only one in Inachus and Macropodia. The antenna differs in the exopodite of Maia, being hardly more than half the length of the spinous process, and ending in three spines, whilst in Inachus and Macropodia the exopodite is pointed, and almost equal in length to the spinous process. In the megalopa the differences are also large. In Maia there are no spines on the carapace, only rounded prominences, and the last joints of the second to the fifth walking legs bear short spines, whereas in Inachus and Macropodia there are distinct spines on the carapace, and the last joints of the legs are long and pointed and the tips only armed with minute spicules. The number of abdominal segments also separate them at once. The young crabs are easily distinguishable, as they bear unmistakable resemblances to the adult.

Inachus and Macropodia can be distinguished from one another with difficulty in the zoeal stages, but one character is quite distinct and reliable, and that is the form of the lateral spine in the telson which in Inachus is large and solid and in Macropodia is slender and small. The megalopæ are quite distinct, Macropodia having a bluntly pointed rostrum bent down so that dorsally the margin looks almost straight, Inachus having the rostrum composed of two distinct straight horns. The young crab stages are distinguishable by the shape of the rostrum and the terminal joints of the two last legs, the rostrum of Macropodia being bifurcate with squarish lobes, that of Inachus bicornuate, and the last two legs in Macropodia having several (never less than three) conspicuous thorns on their last joints, Inachus having only one or two.

The last zoea of all three crabs are backward in development when compared with Maia verrucosa described by Cano and with several other genera described by him from the Mediterranean. He found that the last zoea in these all had jointed antennules, a palp on the mandible and jointed, although rudimentary legs. To this type of zoea he gave the name Metazoea. Cano never saw the second zoea of Macropodia and Inachus, although he figures the first zoea. It is interesting to find that 
these genera are much further back in the development of the second zoea than those others described by Cano, and it is of special interest to find that even in members of the same genus the development is so different, Maia verrucosa being much further advanced than M. squinado in the same stage.

\section{LITERATURE.}

Bell, T. (1853). A History of the British Stalk-eyed Crustacea. London. Borradalle, L. A. (1907). The Classification of the Decapod Crustaceans. Ann. and Mag. Nat. Hist., Ser. 7, Vol. XIX.

Cano, G. (1893). Sviluppo e Morfologia degli Oxyrhyncha. Mitt. Zool. Stat. Neapel., Bd. X, Hft. 4.

Claus, C. (1876). Untersuch. Erf. d. gen. Grund. d. Crust. Syst. Wien.

Couch, R. Q. (1843). On the Metamorphoses of the Decapod Crustacea. Ann. Rep. R. Cornwall Polytechnic Society (not seen personally).

Gourret, P. (1884). Consid. sur la Faune pélagique de Golfe de Marseille. Ann. de Mus. d'Hist. Nat. de Marseille, T. 2, Mem. 2.

Gurney, R. (1924). The Zoea of Eurynome aspera. Journ. Mar. Biol. Assoc., N.S., Vol. XIII, 2.

Gurney, R. (1926). The Protozoeal Stage in Decapod Larvæ. Ann. and Mag. Nat. Hist., Ser. 9, Vol. XVIII.

Hyman, O. W. (1920). The Development of Gelasimus after Hatching. J. of Morph., Vol. 33, No. 2.

Hyman, O. W. (1924). Studies on Larvæ of Crabs of the Family Pinnotheridæ. Proc. U.S. Nat. Mus., No. 2497, Vol. 64, Art. 7.

Kinahan, J. R. (1857). Remarks on the Zoea of Eurynome aspera. Proc. Dublin Nat. Hist. Soc. (not personally seen).

Lo Bianco, S. (1904). Beiträge z. Kennt. d. Meeres, I. Tiefsee-Fischerei der "Maia." Jena.

The Plymouth Invertebrate Fauna (1904). Jour. Mar. Biol. Assoc., Vol. VII, No. 2.

Rathbun, M. J. (1925). The Spider Crabs of America. Smithsonian Inst. U.S. Nat. Mus. Bull., 129.

Schlegel, C. (1911). Sur le développement de Maia squinado Latr. C.R. de l'Acad. Sci., Paris, Vol. 153.

Stephensen, K. (1912). Report on the Malacostraca collected by the Tjalfe Expedition, etc. Vid. Med. f.d. Malin. Foren., Bd. 64. Copenhagen.

NEW SERIES.-VOL. XIV. No. 3. MARCH, 1927. 
Tномpson, J. V. (1836). On the Double Metamorphosis in Macropodia phalangium or Spider Crab. Entomol. Mag., Vol. 3 (not personally seen).

Williamson, H. C. (1900). On the Larval and Later Stages of Hyas araneus $($ L.), etc. Fish. Scot. Sci. Inv.

Williamson, H. C. (1915). Decapoden. I. Theil. (Larven). Nordisches Plankton. Lieferung, 18, VT.

\section{EXPLANATION OF PLATES.}

The figures are drawn to three scales: the pre-zoea and zoea to Scale A, the megalopa and carapace of megalopa and crabs to Scale $\mathrm{B}$, half the scale of $\mathrm{A}$, and the appendages and details of telson abdomen and rostrum to Scale C, three times the scale of A.

\section{PLATE I.}

Fig. 1.-Pre-zoea of Inachus Dorsettensis, about $1.9 \mathrm{~mm}$. long (Scale A).

FIG. 2.-Pre-zoea of Macropodia longirostris, about $2.4 \mathrm{~mm}$. long (Scale A).

Fig. 3.-Pre-zoea of Maia squinado, about $2.5 \mathrm{~mm}$. long (Scale A).

Fra. 4.-Antennule of pre-zoea of Inachus Dorsettensis (Scale C).

Fig. 5.-Antenna of same (Scale C).

Fig. 6.-Telson of same (Scale C).

FIG. 7.-First zoea of Inachus Dorsettensis, about $2.4 \mathrm{~mm}$. long (Scale A).

FIG. 8.-First zoea of Macropodia longirostris, about $2.7 \mathrm{~mm}$. long (Scale A).

FIG. 9.-First zoea of Maia squinado, about $2.9 \mathrm{~mm}$. long (Scale A). 
PLATE I.

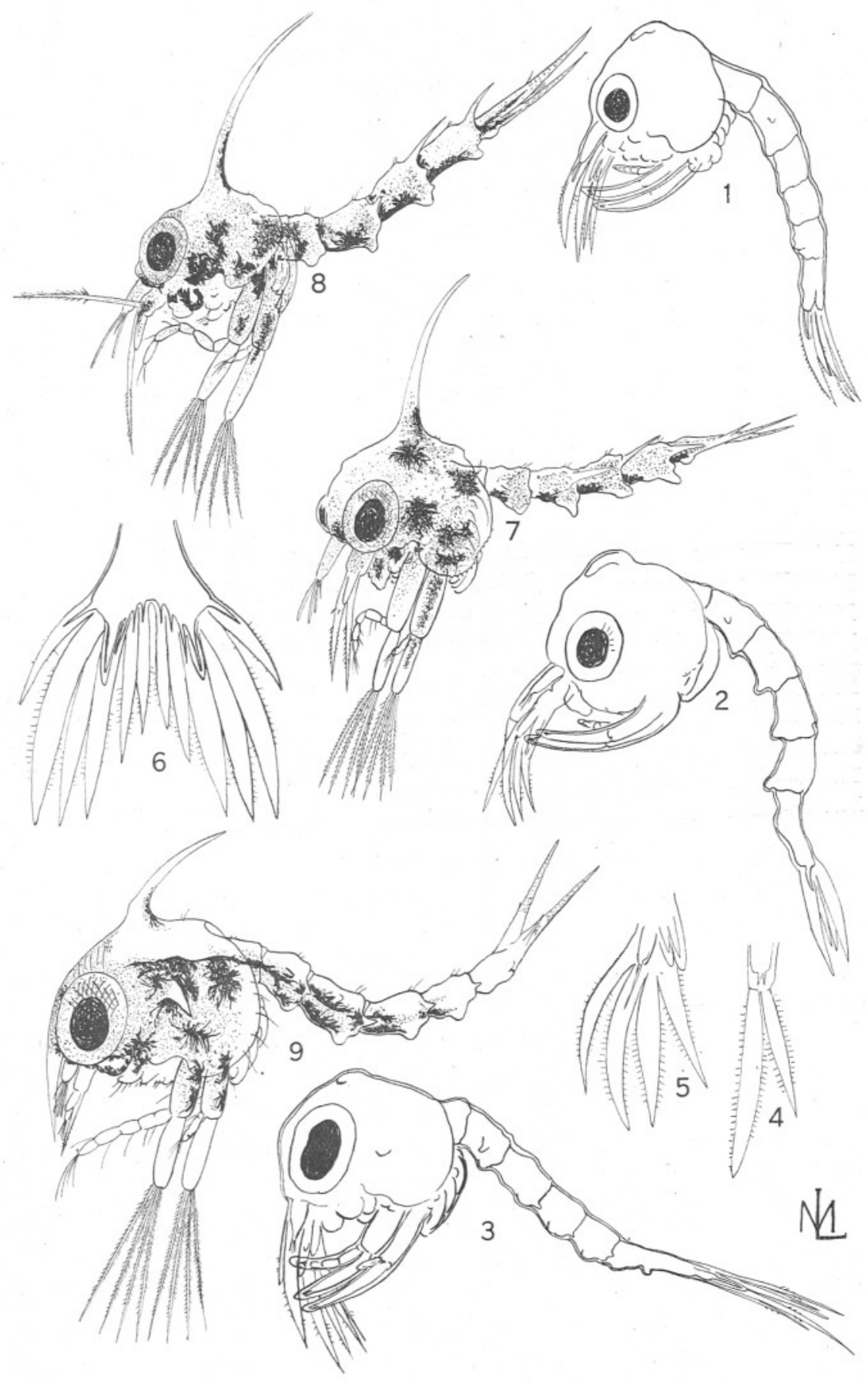




\section{PLATE II.}

Frg. 1.-Second zoea of Inachus Dorsettensis, about $2.9 \mathrm{~mm}$. long (Scale A).

Fig. 2.- Second zoea of Macropodia longirostris, about $3 \mathrm{~mm}$. long (Scale A).

Fig. 3.-Second zoea of Maia squinado, about $3 \mathrm{~mm}$. long (Scale A).

Fig. 4.-Mandible of second zoea of Inachus Dorsettensis (Scale C).

Frg. 5.-First Maxilla of same (Scale C).

Frg. 6.-Second Maxilla of same (Scale C).

Fic. 7.-Telson of same (Scale C).

FIG. 8.-Telson of Macropodia longirostris (second zoea), (Scale C).

Fig. 9.-Telson of Maia squinado (first zoea) (Scale C).

FIG. 10.-Abdomen of megalopa of Inachus Dorsettensis (Scale C). 
PLATE II.

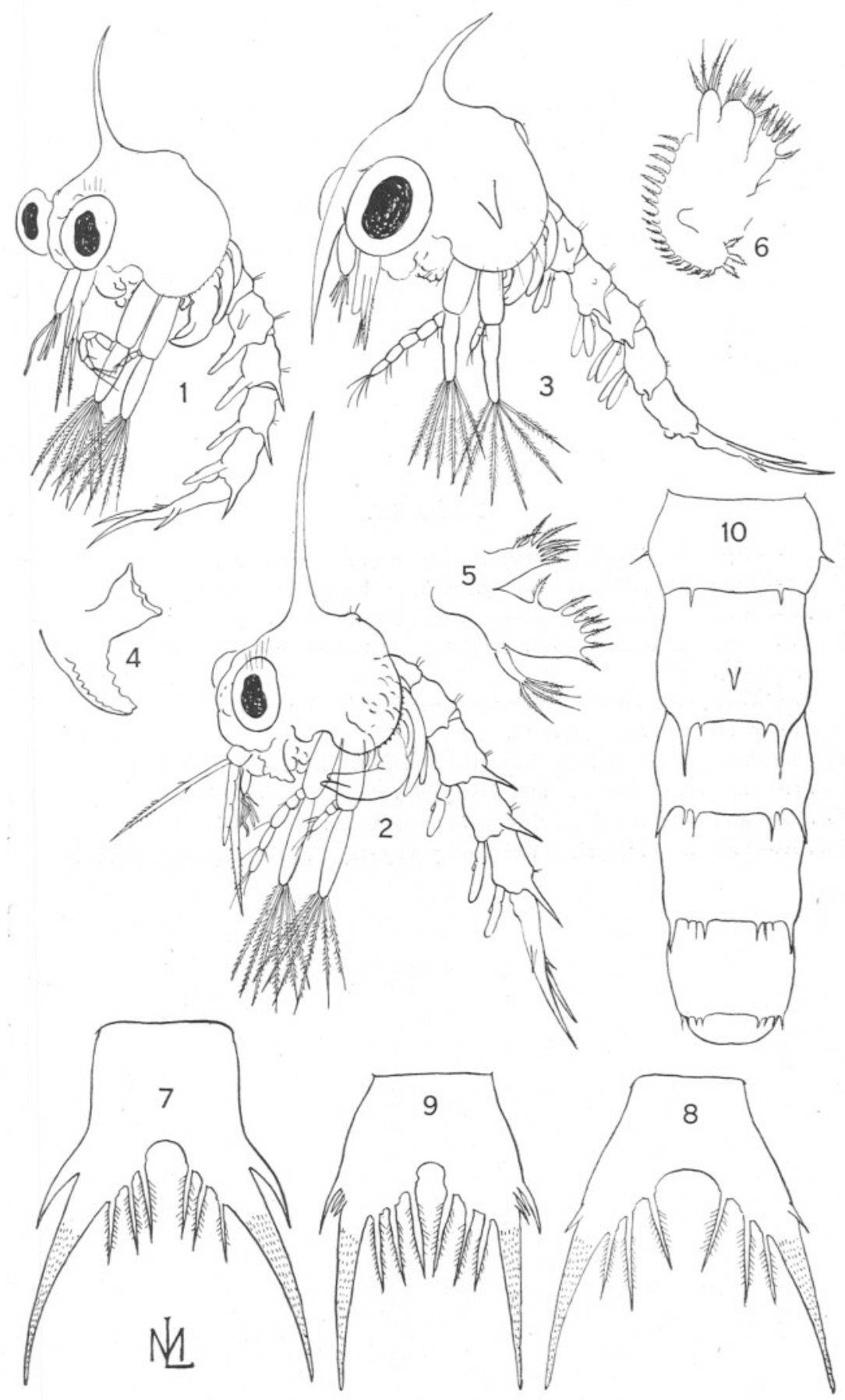




\section{PLATE III.}

FIG. 1.-Megalopa of Inachus Dorsettensis, 1.6 mm. long (Scale B).

Frg. 2.-Megalopa of Macropodia longirostris, $2 \cdot 3 \mathrm{~mm}$. long (Scale B).

FIG. 3.-Megalopa of Maia squinado, $2 \cdot 4 \mathrm{~mm}$. long (Scale B).

FIG. 4.-Megalopa of Macropodia longirostris catching a zoea of Inachus Dorsettensis (Scale B).

FIG. 5.-First young stage of Macropodia longirustris (Scale B).

Fig. 6.-Rostrum of same (Scale C).

Fig. 7.-Carapace of megalopa of Inachus Dorsettensis from side (Scale B).

Fig. 8.-Carapace of megalopa and three young stages of Inachus Dorsettensis (Scale B).

FIG. 9.-Carapace of megalopa of Maia squinado from side (Scale B).

Fig. 10.-Carapace of megalopa and three young stages of Maia squinado (Scale B). 
PLATE III.

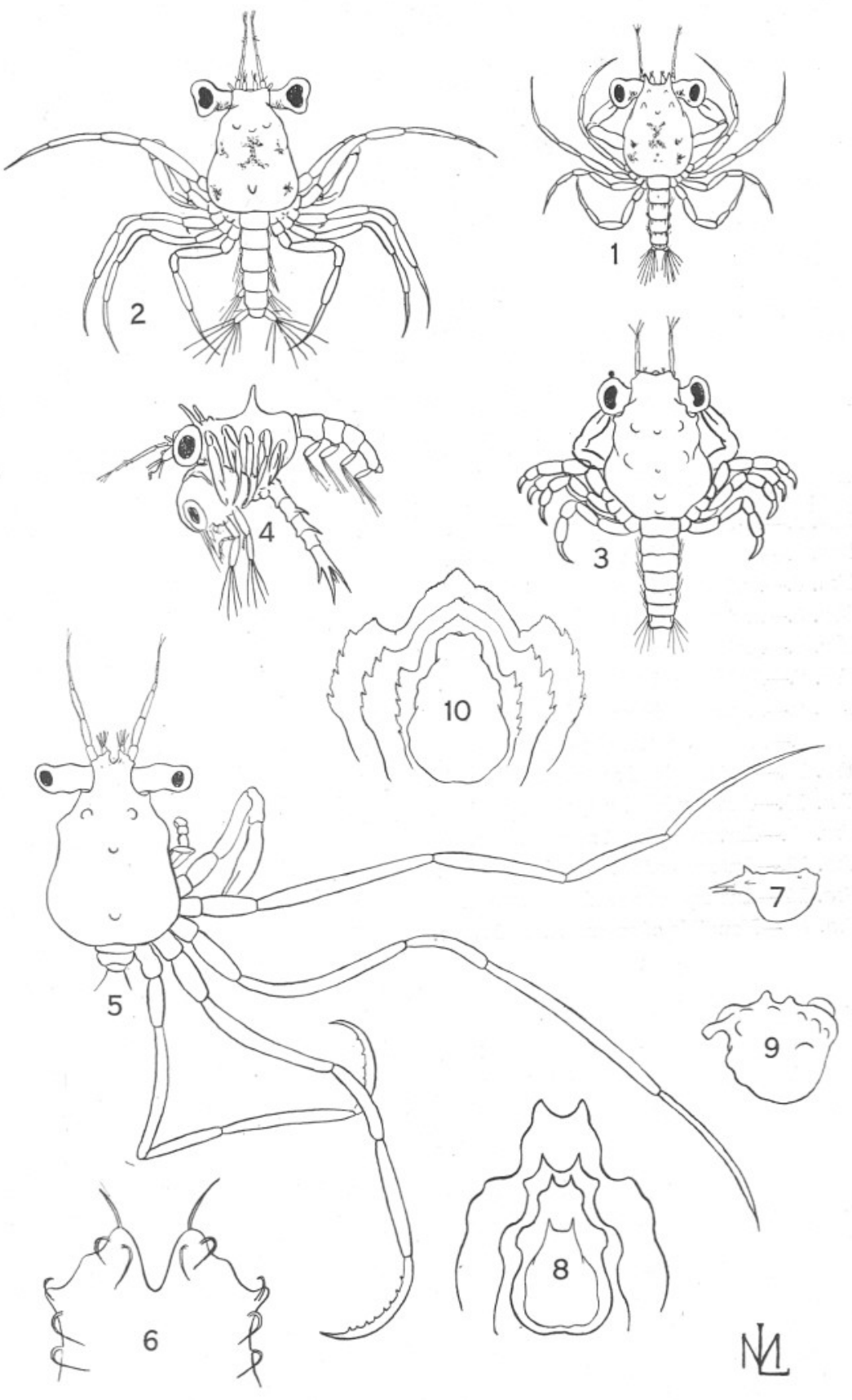




\section{PLATE IV (all Scale C).}

FIG. 1.-Antennule of second zoea of Inachus Dorsettensis.

Fig. 2.-Antennule of megalopa of same.

Fig. 3.-Antenna of second zoea of same.

FIG. 4.-Antenna of megalopa of same.

Fig. 5.-Antennule of second zoea of Macropodia longirostris.

Fig. 6.-Antennule of megalopa of same.

Frg. 7.-Antenna of second zoea of same.

FIG. 8.-Antenna of megalopa of same.

FIG. 9.-Antennule of first zoea of Maia squinado.

FIG. 10.-Antennule of second zoea of same.

FIG. 11.-Antennule of megalopa of same.

Fig. 12.-Antenna of first zoea of same.

Fig. 13.-Antenna of second zoea of same.

Fig. 14.-Antenna of megalopa of same.

FIG. 15.-Mandible of second zoea of same. 
PLATE IV.

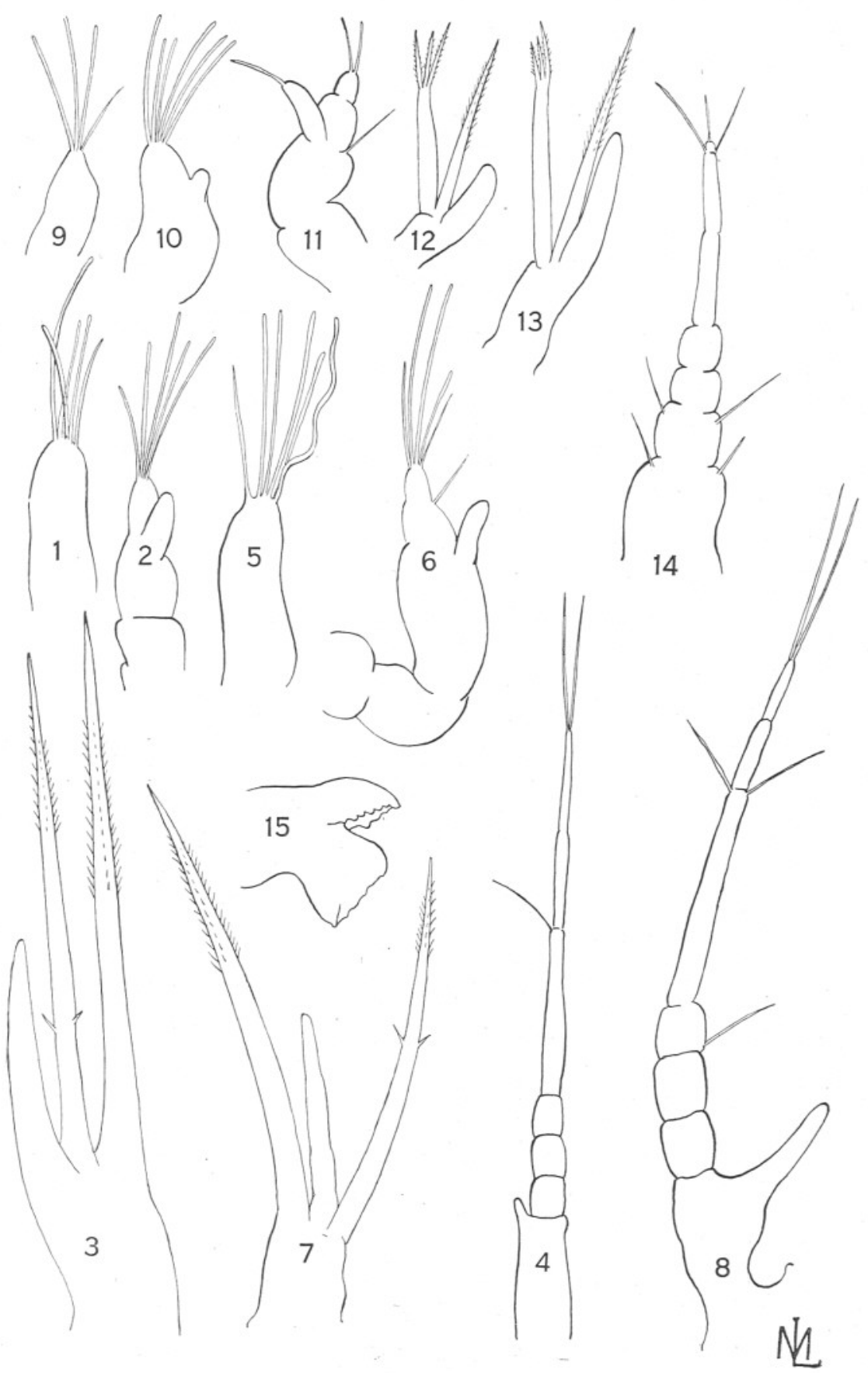


